\title{
NKX2-1 wt Allele
}

National Cancer Institute

\section{Source}

National Cancer Institute. NKX2-1 wt Allele. NCI Thesaurus. Code C73444.

Human NKX2-1 wild-type allele is located in the vicinity of $14 q 13$ and is approximately 4 $\mathrm{kb}$ in length. This allele, which encodes thyroid transcription factor 1 protein, is involved in the modulation of transcription for thyroid specific genes and may play a role in lung development. Mutations in the gene are associated with hypothyroidism, neonatal respiratory distress, and both benign hereditary chorea and choreoathetosis. 